\title{
Sociodemographic Characteristics, School Performance, Pattern of Consumption and Emotional Health as Risk Factors for Alcohol use among Adolescents
}

\begin{abstract}
Angela Helena Marin*, 1
Orcid.org/0000-0002-8056-8661

Ana Carolina Peuker ${ }^{2}$

Orcid.org/0000-0002-9247-9586

Felix Henrique Paim Kessler ${ }^{2}$

Orcid.org/0000-0001-7059-2564

${ }^{1}$ Universidade do Vale do Rio dos Sinos, São Leopoldo, Rio Grande do Sul, Brasil ${ }^{2}$ Universidade Federal do Rio Grande do Sul, Porto Alegre, Rio Grande do Sul, Brasil

Abstract

Objective: It is known that alcohol use has increased both nationally and internationally. The present study was designed to evaluate the extent to wich sociodemographic characteristics, school performance, pattern of consumption and emotional health can predict the variable of interest, recent alcohol use, defined as the consumption of alcoholic beverages in the past 30 days, among adolescents from public schools in the metropolitan region of Porto Alegre/Rio Grande do Sul-Brazil. Methods: This was an observational, analytical, cross-sectional study of 124 students, 70 girls and 54 boys, aged 11 to 18 years. Participants were assessed in the classroom and completed a sociodemographic questionnaire, the Youth Self Report, and a questionnaire on drug use. Results: The variable with the greatest impact on recent alcohol use was total internalizing problems, anxiety/depression, and female sex. First alcohol use at 15 years or younger as well as school failure were also able to predict alcohol use. Conclusion: the data confirm the multidimensionality of the phenomenon that should be considered in prevention campaigns.
\end{abstract}

Keywords: Alcoholic beverages, adolescent behavior, mental health.

* Mailing address: Av. Unisinos, 950 - E01109, São Leopoldo, RS, Brazil 93022-750. E-mail: angelahm@ unisinos.br, acpeuker@hotmail.com and fkessler@hcpa.edu.br

Funding: Conselho Nacional de Desenvolvimento Científico e Tecnológico $(\mathrm{CNPq})$ - Chamada Ministério da Ciência, Tecnologia, Inovações (MCTI)/CNPq/ Ministério da Educação (MEC)/ Coordenação de Aperfeiçoamento de Pessoal de Nível Superior (CAPES) No 18/2012 - Ciências Humanas, Sociais e Sociais Aplicadas. 


\section{Características Sociodemográficas, Desempenho Escolar, Padrão de Consumo e Saúde Emocional como Fatores de Risco para o Uso de Álcool entre Adolescentes}

\section{Resumo}

Objetivo: sabe-se que o consumo de álcool entre adolescentes tem se intensificado no contexto nacional e internacional e em função disso o presente estudo foi concebido para avaliar em que medida variáveis como características sociodemográficas, desempenho escolar, padrão de consumo e saúde emocional podem predizer a variável de interesse, consumo recente de álcool, definido como consumo de bebidas alcoólicas nos últimos 30 dias, entre adolescentes de escolas públicas da região metropolitana de Porto Alegre/Rio Grande do Sul-Brasil. Método: trata-se de um estudo transversal, com delineamento observacional-analítico, do qual participaram 124 escolares, 69 meninas e 55 meninos, com idades entre 11 e 18 anos. Todos foram acessados em sala de aula para responderem ao Questionário de Dados Sociodemográficos, Youth Self Report e Questionário sobre o uso de drogas. Resultados: as variáveis com maior impacto no consumo recente de álcool foram o total dos problemas de internalização, ansiedade/ depressão e sexo feminino. Ter feito uso de álcool com 15 anos ou menos e reprovação escolar também foram capazes de predizer o uso de álcool. Conclusão: os dados confirmam a multidimensionalidade do fenômeno que deve ser considerada em campanhas de prevenção.

Palavras-chave: Bebidas alcoólicas, comportamento adolescente, saúde mental.

\section{Características Sociodemográficas, Desempeño Escolar, Patrón de Consumo y Salud Emocional como Factores de Riesgo para el Consumo de Alcohol entre Adolescentes}

\section{Resumen}

Objetivo: se sabe que el consumo de alcohol entre adolescentes se ha intensificado en el contexto nacional e internacional. En función de ello el presente estudio fue concebido para evaluar en qué medida variables como las características socio-demográficas, el rendimiento escolar, patrón de consumo y la salud emocional pueden predecir la variable de interés, el consumo reciente de alcohol, definido como el consumo de bebidas alcohólicas en los últimos 30 días, entre adolescentes de escuelas públicas de la región metropolitana de Porto Alegre / Rio Grande do Sul-Brasil. Método: se trata de un estudio transversal, con delineamiento observacional-analítico, del cual participaron 124 escolares, 69 niñas y 55 niños, con edades entre 11 y 18 años. Todos fueron accedidos en el aula para responder al Cuestionario de Datos Sociodemográficos, Youth Self Report y Cuestionario sobre el uso de drogas. Resultados: las variables con mayor impacto en lo consumo reciente de alcohol fueron el total de los problemas de internalización, ansiedad/depresión y sexo femenino. Haber hecho uso de alcohol con 15 años o menos y reprobación escolar también fue capaces de predecir el uso de alcohol. Conclusión: los datos confirman lo fenómeno multidimensional que debe ser considerado en campañas de prevención.

Palabras clave: Bebidas alcohólicas, comportamiento adolescente, salud mental.

Alcohol use among adolescents is highly prevalent in the international (Johnston, O'Malley, Bachman, \& Schulenberg, 2013) and national context (Cardoso \& Malbergier, 2014;
Pechansky, Szobot, \& Scivoletto, 2004; Peuker, Fogaça, \& Araújo, 2006; Willhelm et al., 2015). In Brazil, a nationwide survey of psychoactive substance use among public and private middle 
and high school students showed that $60.5 \%$ of adolescents reported having used alcohol in their lifetime, $42.4 \%$ in the past 12 months, and $21.1 \%$ in the 30 days prior to the survey (Carlini et al., 2010). A study conducted in southern Brazil showed that $19 \%$ of 10 - to 12 -year-olds had tried alcohol, indicating an early onset of alcohol use that tends to increase steadily with age, reaching $50 \%$ at $13-14$ years of age and $74 \%$ at $15-16$ years of age (Willhelm et al., 2015). Moreover it is known that alcohol use before 14 years of age is associated with increased risk for substance use disorder at later ages (World Health Organization [WHO], 2014).

Adolescents face a wide range of negative consequences of alcohol use because they are still in the course of biological, emotional, behavioral and social development. Studies have demonstrated how experiences with alcohol that occur during adolescence can render young individuals particularly vulnerable to alcohol misuse and, consequently, how alcohol use can negatively impact brain development, compromising cortical and subcortical regions (Johnston et al., 2013; Pechansky et al., 2004; Peuker et al., 2006). These brain changes may lead to impairment in several cognitive, affective and behavioral processes (e.g., learning, decision making, impulsivity), which in turn may further promote alcohol consumption and the occurrence of alcohol-related problems (e.g., risky sexual behavior). In addition, there are reports of disturbances in the dopaminergic system and in the prefrontal cortex and limbic system pathways that adversely affect behavioral and emotional aspects of development both in the short and long term (Lansford et al., 2008), leading to learning and memory deficits, for example (Pechansky et al., 2004). Thus, alcohol use during adolescence has been correlated with learning difficulties, lack of motivation, and low commitment to school work as well as with school failure, absenteeism, and dropout (Cardoso \& Malbergier, 2014).

In a study of 2268 French students (mean age, 11.5 years), $73 \%$ reported having tried alcohol and 4\% reported having been drunk at least once in their life. Regular alcohol users reported feeling frequently depressed, lacking in confidence, and dissatisfied with their physical appearance and way of life, in addition to perceiving themselves as having more problems in their interactions with parents, peers, and school. They also had a propensity for risk-taking behavior and positive expectations of alcohol consumption compared to other students who did not have a regular drinking pattern (Bailly, Rouchaud, Garcia, Roehrig, \& Ferley, 2015). Altogether, these results suggest that emotional and behavioral problems are also associated with a pattern of regular alcohol use, which may even trigger psychiatric disorders.

Alcohol use during adolescence, therefore, impairs one's ability to achieve and maintain satisfactory psychosocial functioning and wellbeing as recommended by the WHO (Bryce, Boschi-Pinto, Schibuya, \& Black, 2005). In addition, the three major causes of death among adolescents are also correlated with alcohol use, namely: traffic accidents due to drunk driving, suicide, and homicide (Epstein, Hill, Bailey, \& Hawkins, 2013). In this sense, many studies have been concerned with identifying predictors for the early use of alcohol in adolescence. Reviews of the literature, such as Enoch (2011) and Stone, Becker, Huber, and Catalano (2012), have indicated the main predictors associated with alcohol use and highlighted variables of individual, family and social scope, considering them as important risk factors for the current and subsequent development.

In view of the foregoing, it is essential to identify the key factors contributing to alcohol use among adolescents in order to support health prevention actions and strategies for this segment of the population. The present study was therefore designed to evaluate the extent to wich sociodemographic characteristics, school performance, pattern of consumption and emotional health can predict the variable of interest, recent alcohol use, defined as the consumption of alcoholic beverages in the past 30 days, among adolescents from public schools in the metropolitan region of Porto Alegre/Rio Grande do Sul-Brazil. 


\section{Methods}

\section{Study Design and Participants}

This was an observational, analytical, cross-sectional study (Grimes \& Schulz, 2002). The target sample was selected from students attending two public (city-run) schools in the city of São Leopoldo, Rio Grande do Sul, the southernmost state of Brazil. The schools were suggested by the Pedagogical Supervision of the Municipal Department of Education for inclusion in the study because they had requested assistance due to difficulties related to the sociocultural context in which they are embedded and the persistent high rates of school failure of their students (about 20\% students with two or more years of disapproval).

A total of 124 students, 70 girls and 54 boys, participate in the study. The adolescents were aged 11 to 18 years $($ mean $=15.04 ; S D=$ $1.26)$ and $52 \%$ of them had repeated a grade in school (31\% failed one grade, $15 \%$ failed two grades, and $6 \%$ failed three or more grades). All adolescents regularly enrolled in middle school (8th grade) who were allowed and accepted to participate were included in the present study. Students with lower-than-average intellectual potential, which is compatible with severe cognitive deficits, were excluded due to the possible organic etiology of the behaviors observed ( $n=$ 6). The adolescents' intellectual potential was assessed using Raven's Coloured Progressive Matrices (Angelini, Alves, Custódio, Duarte, \& Duarte, 1999).

\section{Procedures and Instruments}

The study project was presented to and approved by the Municipal Department of Education. After approval, the suggested schools were visited and the directors were adequately informed about the project and received detailed explanations about the procedures. School directors signed a consent letter agreeing to participate in the project. Eighth graders and their parents or legal guardians were then invited to attend a meeting to discuss school failure. On this occasion, the proposed research project was presented and they were invited to participate in the study. All adolescents who agreed to participate signed an assent form and their parents or legal guardians provided written informed consent for enrollment in the study. All procedures involving human participants were performed in accordance with the ethical standards of Resolution No. $466 / 12$ of the Brazilian National Health Council (CAAE 05621312.0.0000.5344).

The collection of data occurred during the years 2014 and 2015. Permission was granted by the school director and the teachers in charge of the 8 th grades to administer the questionnaires in the classroom. Participants completed a sociodemographic questionnaire (to provide individual data, such as age and number of failing grades, and information on family members, such as age, marital status, schooling, and type of work of parents and family configuration) and the Youth Self Report (YSR; Achenbach \& Rescorla, 2001, 2004), a questionnaire designed to assess the mental health of adolescents divided into two parts. The first one is composed of items destined to evaluate the competences of adolescents. The second, with 112 questions that are answered on a Likert three-point scale $(0=$ affirmation is not true, $1=$ information is a bit true or sometimes true, and $2=$ affirmation is very true or often true), provides indicators of emotional and behavioral problems as determined by eight scales comprising three general domains: internalizing problems, externalizing problems, and total problems. The first domain consists of the scales related to anxiety and depression, withdrawn/depression, and somatic complaints. The second domain includes delinquent and aggressive behaviors, while the third includes all items related to behavioral problems. For the purposes of the present study, only this second part of the instrument was used. The YSR is currently being validated for use in Brazil and good internal consistency indices have already been reported (Cronbach's alpha ranging from 0.67 to 0.95 ; Bordin et al., 2013).

Finally, participants completed a questionnaire on drug use [adapted from the 
WHO Research and Reporting Project on the Epidemiology of Drug Dependence (Smart et al., 1980) and adapted for use in Brazil (CarliniCotrim, Carlini, Silva-Filho, \& Barbosa, 1989) that was designed to screen the use and pattern of consumption of alcohol and other drugs (tobacco, marijuana, cocaine and derivatives, amphetamines, tranquilizers, anticholinergics, appetite stimulants, barbiturates, opiates, codeine-based cough syrups, solvents, hallucinogens, and other injectable drugs) without a diagnostic purpose. The data were analyzed according to the classification indicators of drug use recommended by the WHO: lifetime use (reported drug use at least once in their life); past 12-month use (at least once in the 12 months prior to the survey); past 30 -day use (at least once in the 30 days prior to the survey); frequent use (6 or more occasions in the 30 days prior to the survey); and heavy use ( 20 or more occasions in the 30 days prior to the survey).

All instruments were administered by undergraduate research scholarship holders who had been previously trained for this purpose. Questionnaire administration lasted approximately 60 minutes and the teacher didn't remain in the classroom during their application. Students who were unwilling to complete the survey protocols were instructed to leave the questionnaire blank.

\section{Data Analysis}

The responses of the YSR instrument were analyzed using the ASEBA-PC software, which includes modules to enter and analyze the data obtained, assigning a profile to each adolescent regarding the scores of internalizing problems, outsourcing problems and total problems, as well as Scores of each of the eight behavioral scales considered. Scores of the contemplated scales can be classified as clinical (percentiles from 70), borderline (percentiles between 65 and 69) and non-clinical (percentiles below 65). This study chose to include adolescents categorized as borderline in the clinical category, as recommended (Achenbach \& Rescorla, 2001).
It should be noted that this classification is not a diagnosis, but it helps to identify indicators of the need for professional help (Achenbach \& Rescorla, 2001). The $T$-scores for each subscale and scale of the instruments were also use, since this standardizes the results, and there were no interference from the corresponding number of items.

Data were analyzed descriptively (absolute and relative distribution) and expressed as median, mean and $S D$. The data distribution of continuous variables was assessed by the Kolmogorov-Smirnov test (Callegari-Jacques, 2003). Pearson's chi-square test $(\chi 2)$ or Fisher's exact test as well as Student's $t$ test were used for bivariate analysis. Because the outcome of interest, recent alcohol use (past 30 days), had a binary distribution, logistic regression analysis using backward elimination was performed to assess the quality of fit of the final model. The Hosmer-Lemeshow test and Nagelkerke $R^{2}$ estimators were considered, and all variables with $p$-values $\leq .10$ in the bivariate analysis were selected for multivariate analysis. The probability for the gradual entry of variables into the model was set at .05 and for removal at .10. For the cutoff point, significance was set at 0.50 for a maximum of 20 interactions. The quality of fit of the regression model was determined by calculating the area under the receiver operating characteristic (ROC) curve. Data were analyzed using SPSS, version 22.0 for Windows, and the level of significance was set at $5 \%$.

\section{Results}

The age at first alcohol use was 12 years $(S D$ $=2.4$ ), with a minimum reported age of 8 years. Of the total sample, $43.5 \%(n=54)$ reported having had their first drink at age 15 years or younger. Of these, $23 \%$ reported that they were offered alcohol for the first time by a family member, $21 \%$ by friends, and $4 \%$ purchased it for themselves. A total of $22 \%$ of adolescents reported having been drunk at least once in their life and $31 \%$ reported having purchased their own alcoholic beverage. 
Regarding the frequency of consumption, $47.9 \%$ reported having consumed alcohol in the past 12 months and $24.2 \%$ in the last month. Of these, $64 \%$ had used in 1 to 5 days, $23 \%$ in 6 to 19 days and $13 \%$ in 20 or more days. Beer was the most commonly consumed alcoholic beverage on the last occasion (33.9\%), followed by wine $(11.3 \%)$, liquor $(6.4 \%)$, and sparkling wine $(6.4 \%)$. In $13 \%$ of cases, the adolescents had four or more drinks. When asked about with whom they drink alcohol more frequently, 18\% reported drinking with a family member and $22 \%$ with friends. Regarding the adolescents' perception of excessive alcohol consumption by their family members, $16 \%$ reported that their father drank too much, $6 \%$ that their mother drank too much, and $23 \%$ that their siblings and/ or other relatives drank too much.

Regarding emotional and behavioral problems, taking into account the overall scores derived from the eight scales evaluated, $55.6 \%$ of adolescents rated themselves as normal ${ }^{1}$, $11.3 \%$ as borderline, and $18.5 \%$ as clinical for total internalizing problems (the remaining $14.5 \%$ refer to missing data). As for total externalizing problems, $63.7 \%$ of adolescents rated themselves as normal, $6.5 \%$ as borderline, and $15.3 \%$ as clinical (the remaining $14.5 \%$ refer to missing data).

The analyses were then stratified by the outcome 'past 30-day alcohol use' (24.2\% of adolescents had used and $75.8 \%$ had not used alcohol in the past 30 days). Thus, initial descriptive statistics were computed by means of bivariate analysis, in which those variables with predictive power for past 30-day alcohol use were identified, as shown in Table 1. Among sociodemographic variables, there was a significant association with $\operatorname{sex}(p<.04)$, indicating that girls had a 2.56-fold higher risk of using alcohol than boys [95\% confidence

According to Achenbach and Rescorla (2001), scale scores are classified into clinical $(\geq \mathrm{p} 70)$, borderline (p65-p69), and nonclinical $(<\mathrm{p} 65)$ ranges. interval (CI), 1.03-6.41], age $(p<.001)$, in which the group reporting first alcohol use at 15 years or younger had 1.78-fold higher odds of using alcohol (95\% CI, 1.42-2.24), and school failure $(p<.02)$, indicating that students with a history of school failure had 2.22-fold higher odds of using alcohol (95\% CI, 1.10-4.49).

Regarding the evaluation of emotional and behavioral problems, there was a significant association with anxiety/depression $(p<.05)$, indicating a higher risk of alcohol consumption for the borderline [odds ratio (OR): $1.84 ; 95 \% \mathrm{CI}$, 1.20-5.34] and clinical (OR: 1.20; 95\% CI, 1.09$2.88)$ ranges. Similar results were obtained for somatization ( $p<.02$; OR: 1.66 ; 95\% CI, 1.112.81 and OR: 1.73 ; 95\% CI, 1.11-2.47, respectively), aggressive behavior ( $p<.04$; OR: 1.11; 95\% CI, 0.95-1.53 and OR: 1.85 ; 95\% CI, 1.225.33 , respectively), and internalizing problems $(p<.01$; OR: 1.05 ; 95\% CI, 0.84-1.16 and OR: $1.22 ; 95 \%$ CI, 1.01-2.07, respectively).

In order to detect which of the investigated variables had potential to predict recent alcohol use (past 30 days), binary logistic regression analysis using backward elimination was performed. To construct the initial (saturated) multivariate model, all variables with $p$-values $\leq$ 0.10 were used as predictive variables (Hosmer $\&$ Lemeshow, 2000), namely: sex $(p<.04)$, age at first alcohol use $(p<.001)$, school failure ( $p<$ $.02)$, anxiety/depression $(p<.05)$, somatization ( $p$ $<.02)$, delinquent behavior $(p<.08)$, aggressive behavior $(p<.04)$, and internalizing problems ( $p$ $<.001)$. Details are shown in Figure 1.

Based on the results obtained, the final model was constructed in eight steps, with the overall model summary showing that, from step 1 to step 8 , the $-2 \log$ likelihood decreased, indicating model improvement from 46.95 in step 1 to 50.15 in step 8 . Nagelkerke pseudo $R^{2}$ increased as predictors were excluded, accounting for $65.5 \%$ of the variance in step 1 and $63.6 \%$ in step 8 .

The following predictive factors remained significant in the validated model: being female, first alcohol use at 15 years or younger, 
Table 1

Association between Sociodemographic Variables, YSR Scales, and Recent Alcohol Use ( $N=24)$

\begin{tabular}{|c|c|c|c|c|c|c|c|c|}
\hline \multirow{3}{*}{ Variables } & $\begin{array}{l}\text { Sample }^{\mathrm{b}} \\
(N=124)\end{array}$ & & \multicolumn{5}{|c|}{ Recent alcohol use ${ }^{a}$} & Odds ratio (OR) \\
\hline & \multirow[b]{2}{*}{$N$} & No & & Yes & 30) & \multirow{2}{*}{$\begin{array}{l}p \\
\%\end{array}$} & \multirow{2}{*}{ OR $(95 \% \mathrm{CI})$} & \\
\hline & & $\%$ & $n$ & $\%$ & $n$ & & & \\
\hline
\end{tabular}

Sex*

Male

Female

54

$$
43.5
$$

70

56.5

46

48.9

26.7

0.04 五

1.0

Age at first alcohol use*

$\mathrm{MD}=18(14.5 \%)$

Older than 15 years
15 years or younger

15 years or younger

49

$46.2 \quad 49 \quad 60.5$

57

53.8

53.8

$32 \quad 39.5$

$25 \quad 100.0$

$0.00 \AA$

1.0

School failure*

$\mathrm{MD}=1(0.8 \%)$

Yes

No

60

$\begin{array}{llll}48.8 & 41 & 43.6 & 19\end{array}$

65.5

$\begin{array}{lllll}51.2 & 53 & 56.4 & 10 & 34.5\end{array}$

Anxiety/depression

$\mathrm{MD}=15(12.1 \%)$

Normal

Borderline

Clinical

63

$\begin{array}{cccccc}83 & 76.1 & 68 & 81.9 & 15 & 57.7 \\ 17 & 15.6 & 9 & 10.8 & 8 & 30.8 \\ 9 & 8.3 & 6 & 7.2 & 3 & 11.5\end{array}$

$0.05 \AA$

1.0

$1.84(1.20-5.34)$

$1.20(1.09-2.88)$

Somatization

$\mathrm{MD}=15(12.1 \%)$

Normal
Borderline
Clinical
Delinquent behavior
$\mathrm{MD}=15(12.1 \%)$

Normal

Borderline

88.5

$0.08 \AA$

1.0

Clinical

Aggressive behavior $\mathrm{MD}=15(12.1 \%)$

$\begin{array}{lcccccccc}\text { Normal } & 86 & 78.9 & 69 & 83.1 & 17 & 65.4 & 0.04 \AA & 1.0 \\ \text { Borderline } & 8 & 7.3 & 6 & 7.2 & 2 & 7.7 & & 1.11(0.95-1.53) \\ \text { Clinical } & 15 & 13.8 & 8 & 9.6 & 7 & 26.9 & & 1.85(1.22-5.33) \\ \begin{array}{l}\text { Internalizing problems } \\ \text { MD=15 (12.1\%) }\end{array} & & & & & & & & 1.0 \\ \text { Normal } & 68 & 62.4 & 58 & 69.9 & 10 & 38.5 & 0.00 \AA & 1.05(0.84-1.16) \\ \text { Borderline } & 15 & 13.8 & 12 & 14.5 & 3 & 11.5 & & 1.22(1.07-2.07) \\ \text { Clinical } & 26 & 23.9 & 13 & 15.7 & 13 & 50.0 & & \end{array}$

Notes. MD: missing data; £: Minimum level of significance for bivariate analysis; ¥: Pearson’s chi-square test with continuity correction; A: Fisher's exact test; *: Student's $t$ test for independent samples.

aPercentages obtained based on total cases in each category of alcohol use in the past 30 days (yes/no). ${ }^{b}$ Percentages obtained based on total valid cases in the sample. 


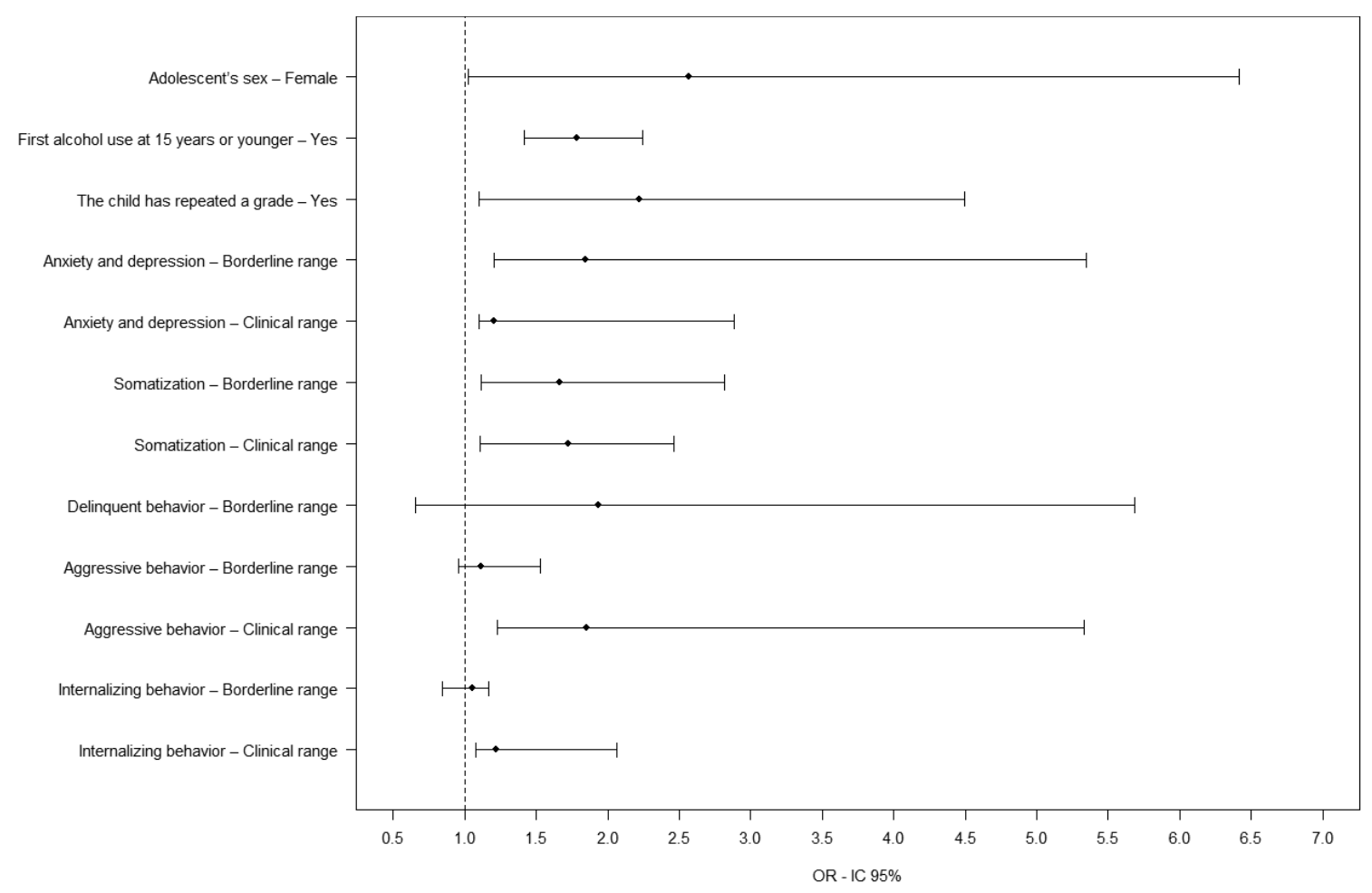

Figure 1. Predictive variables of recent alcohol use (past 30 days).

school failure, borderline/clinical ranges ${ }^{2}$ for anxiety/depression, delinquent behavior, and internalizing problems. This set of variables showed an accurate a posteriori prediction, reaching $84 \%$, being able to accurately classify $70 \%(21 / 30)$ of adolescents who reported using alcohol in the past 30 days and $85.1 \%(80 / 94)$ of those who reported not using alcohol in the past 30 days.

As shown in Table 2, the variable with the greatest impact on the recent alcohol use was total internalizing problems $(\mathrm{b}=1.730 ; p<.001)$, with students classified as borderline/clinical having 3.09-fold higher odds (95\% CI, 1.7211.81) of using alcohol than those classified as normal. Another variable that had a great impact on characterizing the group of adolescents who used alcohol in the past 30 days was anxiety/depression $(b=1.63 ; p<.002)$, indicating a 3.01 fold higher risk (95\% CI, 1.33-8.61) of using alcohol for adolescents classified as borderline/

2 At this point of the analysis, we included the adolescents classified as borderline in the clinical category, as recommended by Achenbach and Rescorla (2001). clinical than for those classified as normal. It should be noted that these scales resulted from the instrument used here. Therefore, although the literature indicates that alcohol use appears to be more closely associated with anxiety and that it may be a comorbidity of depressive states (Silva-Filho \& Silva, 2013), it was not possible to analyze these symptoms separately in the present study.

Finally, female adolescents had a 2.61-fold higher risk (95\% CI, 1.10-6.93) of using alcohol than male adolescents. First alcohol use at 15 years or younger (OR: 2.02; 95\% CI, 1.21-9.51) as well as school failure (OR: 1.88; 95\% CI, 1.06-5.11) were also able to predict alcohol use.

To determine the quality of fit of the logistic regression model, the area under the ROC curve was calculated. The logistic regression model had an area under the ROC curve estimated at 0.75 (95\% CI, 0.63-0.82), which was considered satisfactory (above 0.70 ) and contributed to the assessment of the adequacy of the model to its purpose. The model had a sensitivity of $77.8 \%$ to accurately classify adolescents as alcohol users and a specificity of $81.5 \%$ to accurately classify adolescents as nonusers of alcohol (Figure 2). 
Table 2

Final Model for Multiple Logistic Regression Analysis to Predict Recent Alcohol Use

\begin{tabular}{lcccccc}
\hline & \multicolumn{3}{c}{ Regression coefficient } & \multicolumn{3}{c}{ Adjusted OR } \\
\cline { 2 - 7 } Final model (saturated) & $\mathrm{b}_{\text {crude }}$ & SEb & $p$ & OR & $95 \%$ CI \\
\hline Female & 1.28 & 0.72 & .02 & 2.61 & 1.10 & 6.93 \\
Age at first alcohol use & 2.16 & 0.62 & .02 & 2.09 & 1.20 & 9.51 \\
School failure & 1.08 & 0.76 & .04 & 1.88 & 1.05 & 5.11 \\
Anxiety/depression & 1.63 & 1.09 & .01 & 3.01 & 1.33 & 8.60 \\
Delinquent behavior & 0.92 & 0.23 & .17 & 1.04 & 0.85 & 1.78 \\
Internalizing problems & 1.73 & 0.34 & .01 & 3.09 & 1.72 & 11.81 \\
\hline
\end{tabular}

Notes. $\mathrm{b}_{\text {crude }}$ : Regression coefficient; $\mathrm{SEb}$ : Standard error of the regression coefficient; OR: Odds ratio; $95 \%$ CI: 95\% confidence interval for OR. Nagelkerke $R^{2}=0.636 ; 2 \mathrm{LL}=50.922$; Hosmer-Lemeshow test, $p=.997$.

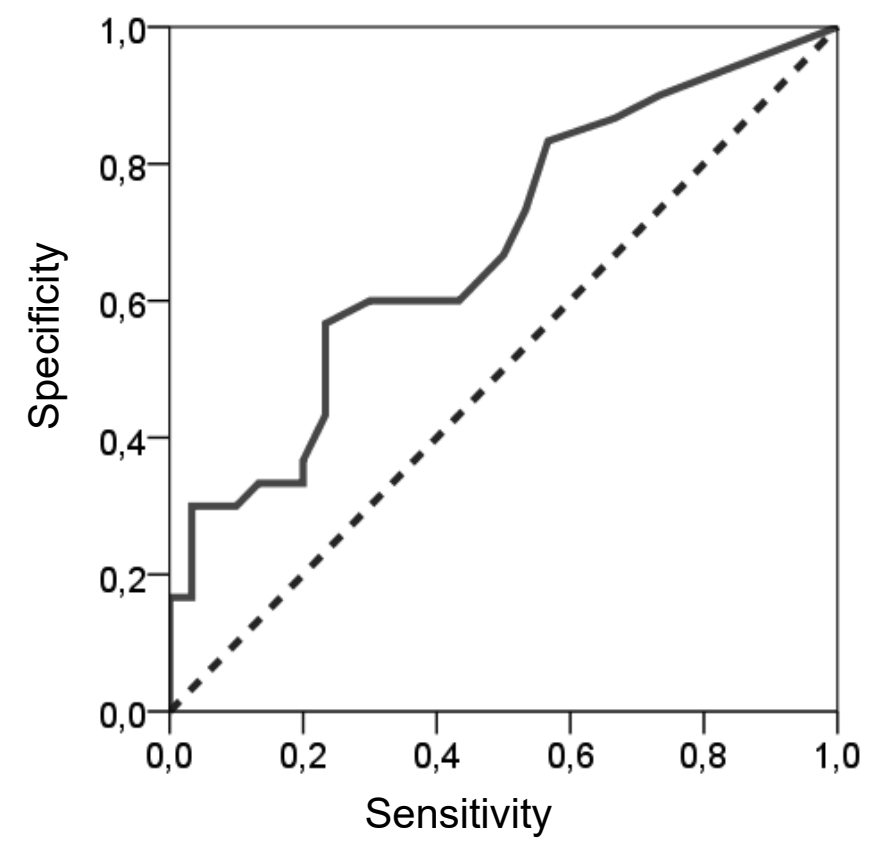

Figure 2. ROC curve for the logistic regression model.

\section{Discussion}

The present study is one of the few investigations conducted in Brazil to evaluate predictive factors for alcohol use among adolescents. Most studies on psychoactive substance use among students focus primarily on epidemiological aspects, and the analysis of more comprehensive variables, in addition to prevalence and incidence estimates for substance use in this population, ends up being neglected. Therefore, the data presented here deserve attention, because they revealed that recent alcohol use, defined as consumption of alcoholic beverages in the past 30 days, is a multidimensional phenomenon, which can be associated with a set of variables related to sociodemographic characteristics (sex), pattern of consumption (age at first use), school performance (failure), and mental health (emotional and behavioral problems). More specifically, the results showed that being female, having tried alcohol before 15 years of age, having repeated a grade in school and experiencing internalizing symptoms, especially 
depression/anxiety symptoms, are associated to recent alcohol use. Altogether, these results suggest that, even at an early age, it is possible to identify a profile prone to alcohol consumption.

Particularly worthy of note are the alarming data found on the age at first alcohol use. The adolescents started using alcohol (onset use) at a mean age of 12 years, and the minimum age reported was 8 years. Epidemiological data show that early adolescent alcohol exposure acts as a potent predictor of adult substancerelated problems (Irons, Iacono, \& Mcgue, 2015). Moreover, clinical studies have shown that substance use tend to increase more rapidly in women than in men, and that women may progress to the development of drug-use disorders and dependence also more quickly (Becker \& Hu, 2008).

Therefore, the earlier the exposure to alcohol, the higher the biopsychosocial problems (Willhelm et al., 2015). Some cultural aspects are known to favor early alcohol use, such as easy access to purchase of alcohol at a relatively low price, its social acceptance, and widespread advertising for consumption of alcoholic beverages. These issues are often overlooked, but they ultimately reinforce the vulnerability of adolescents to substance use disorder at later ages (Pechansky et al., 2004; Peuker et al., 2006).

Another important issue regarding early alcohol exposure is who offers it. It is known that it is often family members who introduce adolescents to alcohol, followed by friends (Dallo \& Martins, 2011). The present study confirms this finding. Studies have demonstrated that the risk of having problems related to the use of psychoactive substances can be enhanced among adolescents whose parents use alcohol at harmful levels due to lack of parental supervision and control over their children's consumption of alcohol (Almeida et al., 2014; Dallo \& Martins, 2011; Willhelm et al., 2015). Parental alcohol abuse is associated with an increased likelihood of drinking more and more frequently among both male and female adolescents, who often drink to higher levels of intoxication (Dallo \& Martins, 2011). However, female adolescents with alcohol misusing mothers (but not fathers) have greater risk of problematic alcohol consumption (Haugland, Holmen, Ravndal, \& Bratberg, 2013).

Recent studies have shown an increasing consumption of alcohol by women, in contrast to previous decades (Almeida et al., 2014), including female adolescents (Dallo \& Martins, 2011). These changes in the pattern of alcohol consumption may be related to changes in women's social status greater participation in social activities resulting from their financial independence (Narain, Liu, Mahmood, \& Duncan, 2017). In addition, the increase in alcohol use among women may also be associated with stress resulting from the women's double burden, which in turn is related to higher education and better economic status (WHO, 2014). Possibly, as a result of these changes, drinking, which was once considered socially unacceptable for women, is now a widely accepted behavior.

Nevertheless, the reasons behind women's problematic alcohol consumption may differ from those of men. Further studies are therefore warranted to explore possible differences in the pattern of consumption of alcohol and other drugs between men and women. While the underlying reasons for these differences remain unclear, certain risk factors may predispose women to substance use disorders, thus requiring special attention with respect to early alcohol use. A longitudinal U.S. study of girls and young women aged 8-22 years revealed that girls became addicted to alcohol faster and tended to suffer the consequences sooner than boys. For many girls, the transition into adolescence was accompanied by decreased self-esteem and selfconfidence. In addition, they were twice as likely to report feeling depressed. As a result, they tended to use alcohol or drugs to improve mood, increase confidence, reduce tension, cope with problems, and lose inhibitions (The National Center on Addiction and Substance Abuse at Columbia University [CASA], 2003).

Alcohol use has many other implications for women's lives. In addition to the greater impact of alcohol on the female body than in the male body due to differences in their biological makeup (Crane, Licata, Schlauch, 
Testa, \& Easton, 2017), alcohol also poses harm to pregnancy and renders women more vulnerable to interpersonal violence (Wilsnack, Kristjanson, Wilsnack, \& Crosby, 2006). Particularly in adolescence, there are reports of early sexual initiation, more experiences of sexual victimization, increased risk for sexually transmitted diseases, and unwanted pregnancy (Greenfield, Keliher, Jacobs, \& Gordis, 1999). It is worrisome that there is evidence that some of these girls can have other negative and relevant consequences as repeat abortions (Keenan, Grundy, Kenward, \& Leon 2014).

Also worthy of note is the finding that beer is the most commonly consumed alcoholic beverage among adolescents, suggesting a greater vulnerability of this population to advertising for this type of alcoholic beverage (Centro de Informações sobre Saúde e Álcool [CISA], 2017). Alcohol advertising is believed to promote the social acceptability of the drug and thus influence both substance use initiation and continued use. In Brazil, there are no restrictions on advertising for alcoholic beverages classified as "weak", with an alcohol content of 13 degrees or lower (beer, vodka/wine coolers, and wine), only for those classified as "strong", with an alcohol content above 13 degrees (whiskey, spirits, and vodka), with a total ban on product marketing on television and radio between 6:00 and 21:00 and on the promotion of alcoholic beverages at sporting events or associating the product with health, driving, and images of success and sexuality. Moreover, safety warning labels are legally required on bottles or containers to avoid excessive consumption and retail stores must warn the customer that driving under the influence of alcohol is a misdemeanor.

A study conducted in Brazil (Faria, Vendrame, Silva, \& Pinsky, 2011) revealed that alcohol advertisements were positively associated with recent beer consumption among adolescents. The results indicated participants identified themselves with the advertising content. In this respect, restrictions on alcohol marketing, regardless of the alcohol content of the beverage, should be implemented in order to prevent alcohol abuse among adolescents. Those authors suggested that media education is also a useful alternative, as it would help to understand how advertisements shape adolescents' understanding of their environment. Following this, an attempt should be made to educate adolescents for the development of critical thinking in a way that helps them make decisions.

The present results also suggest that emotional and behavioral problems, especially indicative of anxiety/depression, render adolescents more vulnerable to alcohol use, which is consistent with the literature (Winters, Stinchfield, Latimer, \& Stone, 2008). A recent study (Johannessen, Andersson, Bjørngaard, \& Pape, 2017) showed higher levels of depression symptoms were associated with earlier onset of alcohol use, more frequent consumption and intoxications. The associations between anxiety and depression symptoms and early drinking onset were stronger for girls than for boys. Corroborating our findings, results of this Norwegian study demonstrated that higher levels of anxiety symptoms were only associated with alcohol consumption among girls.

In this respect, in addition to genetic and environmental factors (community, family, peers), emotional and behavioral problems are viewed as factors predisposing adolescents to alcohol use and should therefore be considered (Saban \& Flisher, 2010; Saraceno, Munafó, Heron, Craddock, \& van den Bree, 2009). Regarding aggressive behaviors there is a strong association between anger and substance abuse. Anger, as other negative emotions, may be a trigger for drug seeking behavior and relapse. Alcohol also is associated, in literature, with hostile attitudes and it increases the likelihood of physical aggression (Johansson et al., 2011).

Finally, we observed that adolescents with higher rates of school failure were more likely to use alcohol at an early age. Alcohol abuse is known to cause cognitive impairments that can lead to learning difficulties and subsequent school failure. Conversely, experiencing school failure may also trigger emotional problems, further promoting alcohol consumption. Considering that current society recognizes the importance of schooling for the social and labor 
insertion of young individuals, it is important to be aware of the potential psychological scars that school failure can leave on those who have experienced it, especially in the event of repeated failure. This is a serious issue for the processes of individuation and social connection, with adverse consequences not only for the adolescent but also for the whole family and community (Benetti, Pizetta, Schwartz, Hass, \& Melo, 2010).

In conclusion, alcohol use is associated with a multitude of negative consequences for adolescents, particularly because they are still in the course of social, biological and emotional development. Alcohol use can affect brain neurochemistry and cause lifelong damage to the emotional health and social adjustment of these young individuals, and the impairment seems to be most striking for girls according to the results obtained in the present study. Therefore, efforts should be directed toward understanding this complex phenomenon, promoting insights into the etiology, consequences and ways of preventing the use of alcohol and other psychoactive substances among adolescents, without limiting the scope to substance characteristics and consumption patterns.

Some limitations of this study should be noted. Since the design of the study is crosssectional, we could not infer causality. Due to the small sample size and local data collection, the present sample cannot be considered a representative sample of the adolescent population in Brazil. Nevertheless, by using robust statistical methods, we were able to analyze the desired results providing significant power and reliability. Further prevention and intervention studies should consider the peculiarities of adolescents' behavior regarding alcohol use, such as the pattern of consumption relative to the number of drinks per occasion, their greater sensitivity to the drug's reinforcing effects, and brain maturation. In addition, new researchers can evaluate the moderating effect of alcohol frequency and intensity, as well as consider comparative analyzes among groups classified by alcohol use intensity, such as adolescents who have never used alcohol, who have used alcohol in their lives and have used in the last 30 days. We believe that the present study shed new light on the understanding of alcohol use among adolescents including biological, psychological and social factors, which may increase the likelihood of success of initiatives aimed at reducing early alcohol use and its current and future negative impact.

\section{References}

Achenbach, T. M., \& Rescorla, L. A. (2001). Manual for the ASEBA school-age forms \& profiles. Burlington, VT: University of Vermont.

Achenbach, T. M., \& Rescorla, L. A. (2004). Mental health practitioners' guide for the Achenbach System of Empirically Based Assessment $A S E B A$ (4th ed.). Burlington, VT: University of Vermont.

Almeida, R. M. M. de, Trentini, L. B., Klein, L. A., Macuglia, G. R., Hammer, C., \& Tesmmer, R. (2014). Uso de álcool, drogas, níveis de impulsividade e agressividade em adolescentes do Rio Grande do Sul. Psico, 45(1), 65-72.

Angelini, A. L., Alves, I. C. B., Custódio, E. M., Duarte, W. F., \& Duarte, J. L. M. (1999). Manual: Matrizes Progressivas Coloridas de Raven. São Paulo, SP: Centro Editor de Testes e Pesquisas em Psicologia.

Bailly, D., Rouchaud, A., Garcia, C., Roehrig, C., \& Ferley, J. P. (2015). Alcohol use in young adolescents. A survey in French secondary schools. Archives de Pediatrie, 22(5), 510-517. doi: 10.1016/j.arcped.2015.02.016

Becker, J. B., \& Hu, M. (2008). Sex differences in drug abuse. Frontiers in Neuroendocrinology, 29(1), 36-47. doi: 10.1016/j.yfrne.2007.07.003

Benetti, S. P. da C., Pizetta, A., Schwartz, C. B., Hass, L. A., \& Melo, V. L. (2010). Problemas de saúde mental na adolescência: Características familiares, eventos traumáticos e violência. Psico-USF, 15(3), 321-332.

Bordin, I. A, Rocha, M. M., Paula, C. S., Teixeira, M. C. T. V., Achenbach, T. M., Rescorla, L. A., \& Silvares, E. F. M. (2013). Child Behavior Checklist (CBCL), Youth Self-Report (YSR) and Teacher's Report Form (TRF): An overview of the development of the original and Brazilian versions. Cadernos de Saúde Pública, 29(1), 1328. doi: 10.1590/S0102-311X2013000100004 
Bryce, J., Boschi-Pinto, C., Schibuya, K, \& Black, R. E. (2005). WHO estimates of the causes of death in children. The Lancet, 365(9465), 1147-1152. doi: 10.1016/S0140-6736(05)71877-8

Callegari-Jacques, S. M. (2003). Bioestatística: Princípios e aplicações. Porto Alegre, RS: Artmed.

Cardoso, L. R. D., \& Malbergier, A. (2014). Problemas escolares e o consumo de álcool e outras drogas entre adolescentes. Psicologia Escolar e Educacional, 18(1), 27-34.

Carlini, E. L. A., Noto, A. R., Sanchez, Z. van der M., Carlini C. M. de A., Locatelli, D. P., Abeid, L. R., ...Moura, Y. G. (2010). VI Levantamento nacional sobre o consumo de drogas psicotrópicas entre estudantes do ensino fundamental e médio das redes pública e privada de ensino nas 27 capitais brasileiras-2010. Brasília, DF: Secretaria Nacional de Políticas Sobre Drogas.

Carlini-Cotrim, B., Carlini, E. A., Silva, A. R., Filho, \& Barbosa, M. T. S. (1989). O uso de drogas psicotrópicas por estudantes do primeiro e segundo graus da rede estadual, em dez capitais brasileiras, 1987. In Consumo de drogas psicotrópicas no Brasil, em 1987. Série C: Estudos e Projetos 5 (pp. 9-84). Brasília, DF: Centro de Documentação do Ministério da Saúde.

Centro de Informações sobre Saúde e Álcool. (2017). Levantamento nacional sobre os padrões de consumo de álcool na população brasileira. Retrieved from http://www.cisa.org.br/ artigo/155/i-levantamento-nacional-sobre-ospadroes.php

Crane, C. A., Licata, M. L., Schlauch, R. C., Testa, M., \& Easton, C. J. (2017). The proximal effects of acute alcohol use on female aggression: A meta-analytic review of the experimental literature. Psychology of Addictive Behaviors, 31(1), 21-26. doi: 10.1037/adb0000244

Dallo, L., \& Martins, R. A. (2011). Uso de álcool entre adolescentes escolares: Um estudo-piloto. Paidéia (Ribeirão Preto), 21(50), 329-334.

Enoch, M. A. (2011). The role of early life stress as a predictor for alcohol and drug dependence. Psychopharmacology, 214(1), 17-31. doi: 10.1007/s00213-010-1916-6

Epstein, M., Hill, K. G., Bailey, J. A., \& Hawkins, J. D. (2013). The effect of general and drugspecific family environments on comorbid and drug-specific problem behavior: A longitudinal examination. Developmental Psychology, 49(6), 1151-1164. doi: 10.1037/a0029309

Faria, R., Vendrame, A., Silva, R., \& Pinsky, I. (2011). Propaganda de álcool e associação ao consumo de cerveja por adolescentes. Revista de Saúde Pública, 45(3), 441-447. doi: 10.1590/ S0034-89102011005000017

Greenfield, S. F., Keliher, A., Jacobs, D., \& Gordis, E. (1999). The development of national alcohol screening day. Harvard Review of Psychiatry, 6(6),327-330.doi:10.3109/10673229909017211

Grimes, D. A., \& Schulz, K. F. (2002). An overview of clinical research: The lay of the land. The lancet, 359(9300), 57-61. doi: 10.1016/S01406736(02)07283-5

Haugland, S. H., Holmen, T. L., Ravndal, E., \& Bratberg, G. H. (2013). Parental alcohol misuse and hazardous drinking among offspring in a general teenage population: Gender-specific findings from the Young-HUNT 3 study. BMC Public Health, 13(1), 1113-1140. doi: 10.1186/14712458-13-1140

Hosmer, D. W., \& Lemeshow, S. L. (2000). Applied logistic regression. New York: John Wiley \& Sons.

Irons, D. E., Iacono, W. G., \& Mcgue, M. (2015). Tests of the effects of adolescent early alcohol exposures on adult outcomes. Addiction, 110(2), 269-278. doi: 10.1111/add.12747

Johannessen, E. L, Andersson, H. W., Bjørngaard, J. H., \& Pape, K. (2017). Anxiety and depression symptoms and alcohol use among adolescents-a cross sectional study of Norwegian secondary school students. BMC Public Health, 17(1), 494. doi: 10.1186/s12889-017-4389-2

Johansson, A., Santilla, P., Corander, J., Jern, P., Von der Pahlen, B., Varjonen, M., \& Sandnabba, K. (2011). Controlling anger in self-reported sober and alcohol intoxicated states: Moderating effects of trait anger and alcohol consumption. Scandinavian Journal of Psychology, 52(4), 382-388. doi: 10.1111/j.1467-9450.2011.00880.x

Johnston, L. D., O’Malley, P. E., Bachman, J. G., \& Schulenberg, J. E. (2013). Monitoring the Future national results on adolescent drug use: Overview, Key Findings on Adolescent Drug use: 2012. Ann Arbor, MI: Institute for Social Research of The University of Michigan.

Keenan, K., Grundy, E., Kenward, M. G., \& Leon, D. A. (2014). Women's risk of repeat abortions is 
strongly associated with alcohol consumption: A longitudinal analysis of a Russian National Panel Study, 1994-2009. PloS One, 9(3), e90356. doi: 10.1371/journal.pone.0090356

Lansford, J. E., Erath, S., Yu, T., Pettit, G. S., Dodge, K. A., \& Bates, J. E. (2008). The developmental course of illicit substance use from age 12 to 22: Links with depressive, anxiety, and behavior disorders at age 18. Journal of Child Psychology and Psychiatry, 49(8), 877-885. doi: 10.1111/j.1469-7610.2008.01915.x

Narain, N., Liu, W. N., Mahmood, Z., \& Duncan, A. (2017). Women's perspectives related to occupational performance following participation in substance use recovery programs. Occupational Therapy in Mental Health, 14(1), 1-14. doi: 10.1080/0164212X.2017.1395309

National Center on Addiction and Substance Abuse at Columbia University. (2003). The formative years: Pathways to substance abuse among girls and young women ages 8-22. New York: Author. Retrieved from https://www.centeronaddiction.org/sites/default/files/The-formativeyears-pathways-to-substance-abuse-amonggirls-and-young-women-ages-8-22_0.pdf

Pechansky, F., Szobot, C. M., \& Scivoletto, S. (2004). Uso de álcool entre adolescentes: Conceitos, características epidemiológicas e fatores etiopatogênicos. Brazilian Journal of Psychiatry, 26(1), 14-17.

Peuker, A. C. W. B., Fogaça, J. L., \& Araujo, L. B. (2006). Expectativas e beber problemático entre universitários. Psicologia: Teoria e Pesquisa, 22(2), 193-200.

Saban, A., \& Flisher, A. J. (2010). The association between psychopathology and substance use in young people: A review of the literature. Journal of Psychoactive Drugs, 42(1), 37-47. doi: 10.1080/02791072.2010.10399784

Saraceno, L., Munafó, M., Heron, J., Craddock, N., \& van den Bree, M. B. M. (2009). Genetic and non-genetic influences on the development of co-occurring alcohol problem use and internalizing symptomatology in adolescence:
A review. Addiction, 104(7), 1100-1121. doi: 10.1111/j.1360-0443.2009.02571.x

Silva-Filho, O. C. da, \& Silva, M. P. da. (2013). Transtornos de ansiedade em adolescentes: Considerações para a Pediatria e Hebiatria. Adolescência e Saúde, 10(3), 31-41.

Smart, R. G., Anumonye, A., Navaratnam, V., Johnston, L. D., Khant, U., Poshyachinda, V., ... Varma, V. K. (1980). A methodology for student drug-use surveys. Genova, Italy: World Health Organization. Retrieved from http://apps.who. int/iris/bitstream/10665/37206/1/WHO_OFFSET_50.pdf

Stone, A. L., Becker, L. G., Huber, A. M., \& Catalano, R. F. (2012). Review of risk and protective factors of substance use and problem use in emerging adulthood. Addict Behavior, 37(7), 747-775. doi: 10.1016/j.addbeh.2012.02.014

World Health Organization. (2014). Global status report on alcohol and health. Genebra: Author. Retrieved from http://apps.who.int/iris/bitstre am/10665/112736/1/9789240692763_eng.pdf

Willhelm, A. R., Cabral, J. C. C., Steiger, J. O., Silva, J. F. F. da, Ugart, L. M., \& Almeida, R. M. M. (2015). Consumo de álcool na adolescência e relação com uso excessivo de bebidas alcoólicas dos pais: Estudantes de quatro escolas de Porto Alegre. Psico, 46(2), 208-216.

Wilsnack, R. W., Kristjanson, A. F., Wilsnack, S. C., \& Crosby, R. D. (2006). Are US women drinking less (or more)? Historical and aging trends, 1981-2001. Journal of Studies on Alcohol, 67(3), 341-348. doi: 10.15288/jsa.2006.67.341

Winters, K. C, Stinchfield, R. D., Latimer, W. W., \& Stone, A. (2008). Internalizing and externalizing behaviors and their association with the treatment of adolescents with substance use disorder. Journal of Substance Abuse Treatment, 35(3), 269-278. doi: 10.1016/j.jsat.2007.11.002

Received: $26 / 11 / 2017$

$1^{\text {st }}$ revision: $25 / 05 / 2018$ Accepted: 30/05/2018

(c) BY The Author(s), 2018. Open Access. This article is distributed under the terms of the Creative Commons Attribution 4.0 International License (http://creativecommons.org/licenses/by/4.0/), which permits unrestricted use, distribution, and reproduction in any medium, provided you give appropriate credit to the original author(s) and the source, provide a link to the Creative Commons license, and indicate if changes were made. 